\title{
THE LAW OF NATIONS AS PART OF THE NATIONAL LAW OF THE UNITED STATES
}

Edwin D. Dickinson $\dagger$

It is an ancient and a salutary feature of the Anglo-American legal tradition that the Law of Nations is a part of the law of the land to be ascertained and administered, like any other, in the appropriate case. This doctrine was originally conceived and formulated in England in response to the demands of an expanding commerce and under the influence of theories widely accepted in the late sixteenth, the seventeenth and the eighteenth centuries. It was brought to America in the colonial years as part of the legal heritage from England. It was well understood by men of legal learning in America in the eighteenth century when the United Colonies broke away from England to unite effectively, a little later, in the United States of America. In the ensuing years of national growth, some of its postulates were abandoned in political controversy; and some became blurred, chiefly in consequence of an increasing absorption in problems of internal development. Others took firm root to become unique features of American federalism. All this may be understood if we begin with at least a brief sketch of the original heritage. With the heritage before us, we should be prepared to consider in somewhat greater detail its influence upon the formation and the implementing of the national constitution. Thereafter, in a sequel to the present paper, we shall review the progress of the Law of Nations in the United States, taking account both of ideas which were abandoned or modified and of ideas which have become firmly established in what may be described fairly as the American constitutional tradition.

II

It is to be emphasized at the outset that the Law of Nations in the eighteenth century embraced a good deal more than the body of practice and agreement which came later to be called public international law. In the De Jure Belli ac Pacis of Hugo Grotius and in

$\dagger$ Professor of Law, University of Pennsylvania Law School; Member on the part of the United States of the Permanent Court of Arbitration; President of the American Society of International Law; author of books and articles on International Law and related subjects. 
the treatises of his successors, it had been expounded as a universal law binding upon all mankind. ${ }^{1}$ In countries of the common law, at least, arbitrary distinctions between private and public right or duty were still far in the future. The universal law was law for individuals no less than for states. As such, it was concerned somewhat indiscriminately with matters between individuals, between individuals and states, and between states. As yet unhindered by the dogmas of more restrictive classification, its major divisions were essentially the product of historical evolution. English lawyers were accustomed to identify the major divisions as the law of merchants, the law maritime, and what, for want of a better name, we may call the law of states.

The law of merchants was of ancient lineage and throughout much of its history had been intimately related to the law maritime. Like the latter, it had become a peculiar heritage of traders, whether subject or alien, and like the latter also it had grown up in customary observances and had long been administered by separate courts. In its application to the internal trade of England, it had been largely absorbed into the common law by the end of the sixteenth century; and by the end of the seventeenth century it had been similarly absorbed in its application to foreign trade without losing its distinctive character as a species of jus gentium. ${ }^{2}$ In resolving the case for the indorsee against the drawer of a foreign bill of exchange drawn by a merchant of London on a merchant of Rotterdam, Justice Eyres had observed in 1691: "it is no more than the law of merchants, and that is jus gentium, and we are to take notice of it." Other justices agreed, Chief Justice Holt remarking: "the time is well enough by the law of merchants, and that is the same with our law." 3 The adoption of the law of merchants into the common law reached maturity in the eighteenth century, with eloquent emphasis upon its international character, in the great opinions of Lord Mansfield. Blackstone was only summarizing the understandings of his time when he said:

"Whereas no municipal laws can be sufficient to order and determine the very extensive and complicated affairs of traffic and merchandize; neither can they have a proper authority for this purpose. For as these are transactions carried on between the subjects of independent states, the municipal laws of one

1. See Dumbauld, Hugo Grotius: The Father of International Law, 1 JouRnaL of Public Law 117, 118, 120, 126 (1952).

2. See 1 Holdsworth, A History of Englist Law, 300-337 (1903); also in 1 Select Essays in Anglo-American Legal History 289-331 (1907). 1691).

3. Mogadara v. Holt, 1 Show. K.B. 317, 318, 319, 89 Eng. Rep. 597, 598 (K.B. 
will not be regarded by the other. For which reason the affairs of commerce are regulated by a law of their own, called the law merchant or lex mercatoria, which all nations agree in and take notice of. And in particular the law of England does in many cases refer itself to it, and leaves the causes of merchants to be tried by their own peculiar customs; and that often even in matters relating to inland trade, as for instance with regard to the drawing, the acceptance, and the transfer, of bills of exchange." 4

The law maritime boasted an even greater antiquity and a more impressive universality. As developed in customs and formulated in early codes for the regulation of sea-borne commerce, it had been fostered in the mediaeval shipping centers of the Mediterranean, had moved later up the west coast of Europe, and had established its authority over the North Sea and in the Baltic wherever carriage by sea was of commercial consequence. It had been received at a very early date in England, where its administration became the responsibility of a separate branch of the judiciary and where its practice was long the exclusive province of a bar trained in the Civil Law. The High Court of Admiralty, notwithstanding the impairment which its jurisdiction suffered in conflicts with Lord Coke in the seventeenth century, had been able to maintain and develop the law maritime as an important part of English law. This court had found frequent occasion to emphasize the proposition that it was administering a branch of the universal jus gentium. Again, it was pre-eminently Lord Mansfield in the eighteenth century who took up the proposition broadly and made it a postulate of the common law. About midway in the century, there came before Mansfield a shipowner's suit to recover the freight earned on fish shipped from Newfoundland to Lisbon. The vessel had been taken by the French, retaken by an English privateer, and brought into an English port, where it was abandoned to insurers. The shipper having accepted his fish at the English port and forwarded them to another market, the case turned upon his asserted obligation to pay the shipowner freight pro rata. Holding that he was required to pay, Lord Mansfield supported his conclusion by citing the Rhodian laws, the Consolato del Mare, the laws of Oléron, the laws of the Hanse Towns, the laws of Wisbuy and the Ordinance of Louis XIV. The great judge declared: "the maritime law is not the law of a particular country, but the general law of nations." 5 Such, needless to emphasize, became accepted English doctrine in the eighteenth century. The law maritime was a

4. $1 \mathrm{BL}$. CoMra. 263-264 (1st ed. 1765-1769).

5. Iuke v. Lyde, 2 Burr. 882, 887, 97 Eng. Rep. 614, 617 (K.B. 1759). 
branch of the Law of Nations. It had been received in England and was to be applied by English courts, on the common law side no less than in admiralty, whenever matters appropriate for its application were duly presented.

A third major division of the Law of Nations as understood by English lawyers of the eighteenth century we have called the law of states. The term, it is to be emphasized, is one of convenience. It is without pride of ancestry and presumably without hope of posterity. It may serve nevertheless to denote the amorphous but considerable body of usage and agreement with respect to international matters which had come into being with the rise of a European state system, which had been enriched by borrowings and adaptations from the Roman Law and by recourse to a Law of Nature, and which, though by no means inapplicable to individuals inter se or in relation to states, was generally of more immediate concern to states than either the law of merchants or the civil law maritime. Ultimately most of it would be absorbed in one way or another into the so-called public international law of a later age. Meanwhile, on the criminal side, it served to define at least a few individual offences. The familiar examples were piracy and attacks upon ambassadors. On the civil side, it sought to encompass and order an expanding body of international relationships in their impact upon individuals and upon states. Men of learning in the eighteenth century were wont to find apt examples in usage or agreement with respect to captures, diplomatic privilege and treaties.

The Law of Nations embraced in the eighteenth century few principles, if any, which were of more ancient lineage or universal acceptance than those applicable to piracy. For obvious reasons, if history were to be probed, they would be found to be almost as ancient as the law maritime. Certainly there was nothing then attributed to the law of states of a more respectable antiquity. The pirate was hostis humani generis and as such a universal criminal subject to universal jurisdiction. "As therefore he has renounced all the benefits of society and government," said Blackstone, "and has reduced himself afresh to the savage state of nature, by declaring war against all mankind, all mankind must declare war against him; so that every community hath a right, by the rule of self-defence, to inflict that punishment upon him, which every individual would in a state of nature have been otherwise entitled to do, for any invasion of his person or personal property." " Accordingly, Blackstone included piracy among "the principal cases, in which the statute law of England inter-

6. $4 \mathrm{BL}$. CoMM. 71. 
poses, to aid and enforce the law of nations, as a part of the common law; by inflicting an adequate punishment upon offences against that universal law, committed by private persons." 7

Also included among "the principal offences against the law of nations, animadverted on as such by the municipal laws of England," was "infringement of the rights of ambassadors." 8 The modern record begins, for all practical purposes, with the Act of Anne enacted in 1708 following the arrest in London of the Russian ambassador at the suit of creditors. ${ }^{9}$ The Act began with a recital that "turbulent and disorderly persons" had insulted His Excellency by arresting him and taking him by violence out of his coach in the public street and detaining him in custody for several hours "contrary to the Law of Nations, and in prejudice of the rights and privileges which ambassadors and other public ministers, authorized and received as such, have at all times been thereby possessed of, and ought to be kept sacred and inviolable." 10 It then proceeded to avoid all such suits and to enact implementing legislation, including penalties, for the future. In Blackstone's view, reflecting a view accepted generally in the eighteenth century, this statute was "not to be considered as introductive of any new rule, but merely as declaratory of the old fundamental constitutions of the kingdom; without which it must cease to be a part of the civilized world." 11 Blackstone concluded:

"As to the rights of embassadors, which are also established by the law of nations. . . . It may here be sufficient to remark, that the common law of England recognizes them in their full extent. . . . And the more effectually to enforce the law of nations in this respect, when violated through wantonness or insolence, it is declared by the statute 7 Ann. c. 12 that all process whereby the person of any embassador, or of his domestic or domestic servant, may be arrested, or his goods distreined or seized, shall be utterly null and void; and that all persons prosecuting, soliciting, or executing such process, being convicted by confession or the oath of one witness, before the lord chancellor and the chief justices, or any two of them, shall be deemed violators of the laws of nations, and disturbers of the public repose, and shall suffer such penalties and corporal punishment as the said judges, or any two of them, shall think fit." 12

7. 4 id. at 68,73 .

8. 4 id. at 68 .

9. 7 ANNE c. 12.

10. For an historian's account of the earlier practice, see AdATR, THE ExTerRItorality of AMbassadors in the SiXteenth aND Seventeenth Centuries (1929).

11. 4 BL. COMM. 67.

$12,4 \mathrm{id}$. at $70-71$. 
On the civil side, the rise of English maritime power had long since made the practice with respect to captures a matter of prime importance. Admiralty courts had responded by developing principles of prize law which were assumed to have been taken from and to be in conformity with the usages and agreements of nations. Writing of the origin of the High Court of Admiralty and of the early develop: ment of its exclusive prize jurisdiction, Marsden tells us that "the recognition of a law of nations, to which the judgments of the Court must conform, appears incidentally in the records during the sixteenth and becomes prominent in the following century." 13 For the eighteenth century we again find a noteworthy pronouncement in one of Mansfield's opinions. Ruling that even a capture ashore by the sea and land forces from a fleet, after the place had been surrendered, was within the jurisdiction of the prize court, Lord Mansfield said:

"By the law of nations, and treaties, every nation is answerable to the other for all injuries done, by sea or land, or in fresh waters, or in port. Mutual convenience, eternal principles of justice, the wisest regulations of policy, and the consent of nations, have established a system of procedure, a code of law, and a court for the trial of prize. Every country sues in these courts of the others, which are all governed by one and the same law, equally known to each." 14

Of the question of prize or no prize, Blackstone had already written: "being a question between subjects of different states; it belongs entirely to the law of nations, and not to the municipal laws of either country, to determine it." 15 The famous pronouncements which Lord Stowell was to make from time to time in the same vein, after his appointment to the High Court of Admiralty in 1798, were no innovation. ${ }^{16}$ They were simply eloquent repetitions of a proposition long since established broadly and firmly in the English law.

On the civil side, also, these same basic ideas had a notable application and elaboration in matters of diplomatic privilege. Again, the modern story begins with the Act of Anne. This statute contained important regulatory provisions which were to prove of greater

13. Marsden, Prize Law, 15 J. Soc'y. Comp. LEG., N.S. 90, 91 (1915).

14. Lindo v. Rodney, in LeCaux v. Eden, 2 Doug. 594, 613 n., 99 Eng. Rep. 375,385 (K.B. 1782).

15. $3 \mathrm{BL}$ CoMM. 69, 108.

16. See The Maria, 1 C. Rob. 340, 350, 165 Eng. Rep. 199 (Adm. 1799); The Recovery, 6 C. Rob. 341, 348, 165 Eng. Rep. 955, 958 (Adm. 1807). In the latter case, Lord Stowell said: "In the first place it is to be recollected, that this is a Court of the Law of Nations, though sitting here under the authority of the King of Great Rritain. It belongs to other nations as well as to our own; and what foreigners have a right to demand from it, is the administration of the law of nations, simply, and exclusively of the introduction of principles borrowed from our own municipal jurisprudence, to which, it is well known, they have at all times expressed no inconsiderable repugnance." 
utility than its penal sanctions. It recognized the jurisdictional immunities to which diplomatic personnel and their domestic servants were assumed to be entitled in the eighteenth century and sought to safeguard them by voiding every improper process and otherwise. U1timately there was much business for the courts. The courts were consistently insistent that the statute was only declaratory of the Law of Nations, that this law was part of the law of England, and accordingly that in interpreting and applying the statute they were proceeding in conformity with the jus gentium of diplomatic privilege. Thus, in 1735, Lord Chancellor Talbot observed in Barbuit's Case that the Act was "only declaratory of the antient universal jus gentium." 17 Lord Mansfield, who was counsel in Barbuit's Case, asserted later that there was never any doubt that the Law of Nations was part of the law of England, that the Act of Anne was declaratory only, and that it was not intended to vary "an iota from it." "This privilege of foreign ministers and their domestic servants," said Mansfield, "depends upon the law of nations." 18 The Commentaries of Blackstone contained a clear and characteristic summation of the same ideas.

Unlike captures, which in eighteenth century England were adjudicated in the prize court as a matter of course, or disputes as to diplomatic privilege, which presented with increasing frequency issues for the determination of a court of common law, controversies with respect to treaties were not a subject of immediate or frequent concern to the judiciary. The making and execution of treaties, needless to say, belonged in England to the Crown and Parliament. Where "mutual compacts, treaties, leagues, and agreements" had ordered the intercourse of states, it was assumed generally that recourse must be had in the event of dispute to "the law of nature and reason, being the only one in which all the contracting parties are equally conversant, and to which they are equally subject." ${ }^{19}$ Controversies at such a level were not for the courts. Theirs was a more prosaic role. There is ample evidence, however, that the English bench and bar of the eighteenth century were becoming increasingly conscious of the importance of treaties in the Law of Nations. Professional opinion was expressed generally in patterns shaped by the writings of the great publicists with which bench and bar were of course familiar. That treaties were binding in a legal sense was a premise universally accepted. Violations, particularly such as might provide excuse for war, were universally deprecated. Sometimes the reference was to

17. Cas. t. Talb. 281, 282, 25 Eng. Rep. 777 (Ch. 1735).

18. Triquet v. Bath, 3 Burr. 1478, 1480, 97 Eng. Rep. 936, 937 (K.B. 1764).

19. 1 BL. Cosm. $43 ; 4$ id. at 67. 
treaties as an evidence or source of the law of states. At other times it was to "the Law of Nations and Treaties," a formula which suggests that treaties were regarded as a separate and significant manifestation of the exercise of state power in mutual intercourse as ordered by the Law of Nations in its most embracing aspect. Whatever the reference, treaties were of or within the Law of Nations and the Law of Nations was part of the law of England.

So much by way of sketch of the American legal heritage from England with which we are presently concerned. Prior to the revolution in America and the adoption of a national constitution, English ideas with respect to the Law of Nations had taken root in the colonies and on occasion had flourished notably. While the law of merchants was perhaps of less consequence in the colonial economy than in England, at least internally, we have found no evidence that it was regarded differently than it had come to be regarded in the mother country. The law maritime had a considerable development in viceadmiralty and other courts in the colonies; and here the continuing progress of the jus gentium of sea-borne trade appears to have been even less obstructed by parochial influences than it was in England after the time of Lord Coke. The law of states flourished as opportunity presented, though naturally this branch of the Law of Nations could have no more than a somewhat occasional application before national independence had been achieved. Nevertheless, there were some notable and revealing instances, particularly in the years of an emerging nationhood.

There were of course some famous piracy trials in America in the colonial period; and it is noteworthy that they were prosecuted and resolved in reliance upon the Law of Nations as they would have been prosecuted and resolved in England. ${ }^{20}$ In 1784, between the Declaration of Independence and the adoption of the Constitution, there was an indictment in the Court of Oyer and Terminer at Philadelphia for threatening bodily harm and for assaulting the Secretary of the French Legation "in violation of the law of nations, against the peace and dignity of the United States and the Commonwealth of Pennsylvania." Chief Justice M'Kean of Pennsylvania, presiding, is reported to have said to the jury: "This is a case of the first impression in the United States. It must be determined on the principles of the laws of nations, which form a part of the municipal law of Pennsylvania; and, if the offences charged in the indictment have been committed, there can be no doubt, that those laws have been violated." (1925).

20. See Dickinson, Is the Crime of Piracy Obsolete?, 38 HARv. L. Rev. 334 
Upon a verdict of guilty on both counts, and after again admonishing that the crime was "an infraction of the law of nations" and that "this law, in its full extent, is part of the law of this State," the court sentenced the accused to pay a fine of one hundred French crowns, to serve a little more than two years in prison, and to post security to keep the peace for seven years thereafter. ${ }^{21}$

On the civil side, the English conception of jurisdiction and law with respect to maritime captures was approved at an early date. The traditional English approach was affirmed clearly in judicial opinions both before and after the adoption of the national constitution. ${ }^{22}$ Justice Story was merely reaffirming a familiar postulate a generation later when he declared that "the Court of prize is emphatically a Court of the law of nations; and it takes neither its character nor its rules from the mere municipal regulations of any country." ${ }^{23}$ On the civil side, also, it is pertinent to remind that the first Congress of the United States would enact in 1790 a statute, in substantial imitation of the Act of Anne, which voided all writs and processes against ambassadors or other public ministers. ${ }^{24}$ With the achievement of independence, there was as little doubt among men of legal learning in America as in England that the Law of Nations was adopted in its full extent as part of the law of the land and that it was the responsibility of courts to apply it like any other law when the appropriate case was presented.

\section{III}

The progress of the Law of Nations as part of the law of the land in the United States was briefly but sharply forecast in the Declaration of Independence. From the assertion that "these United Colonies are, and of right ought to be, Free and Independent States," it followed as a matter of course that "as Free and Independent States, they have full power to levy war, conclude peace, contract alliances, establish commerce, and do all other acts and things which Independent States may of right do." Nothing less could assure the separate and equal station to which "the Laws of Nature and of Nature's God" entitled them. With the disasters and triumphs of the Revolution, or the tribulations of the period under "Articles of Confederation and Perpetual Union" which proved to be neither perpetual nor union, we

21. Respublica v. De Longchamps, 1 Dall. 111 (1784).

22. See Miller v. The Ship Resolution, 2 Dall. 1, 19 (Federal Court of Appeals 1781) ; Talbot v. The Commanders, 1 Dall. 95 (High Court of Errors and Appeals of Pennsylvania 1784); Talbot v. Janson, 3 Dall. 133, 157, 159, 169 (U.S. 1795).

23. The Schooner Adeline, 9 Cr. 244, 284 (U.S. 1815).

24. Act of April 15, 1790, c. 9, §§ 25-28, 1 STAr. 112, 117. 
need not concern ourselves. ${ }^{25}$ It is enough to recall that these were the years in which it became progressively and too painfully apparent that the great principles of the Declaration could never be implemented through partial and separate effort and that "a more perfect union" was indispensable to national survival.

If we are to understand the plan for "a more perfect union" which a constitutional convention was soon to produce, it is essential that we recapture something of the ideological climate of the time. It was late in the eighteenth century. Excepting only the ideals of religion, there were probably no ideals of such impact upon the minds of men as the ideals of law. Leaders in law had a knowledge of contemporary legal thought and of the great legal systems which has rarely been equalled since in this country. It was axiomatic among them that the Law of Nations, applicable to individuals and to states, was an integral part of the law which they administered or practiced. The great principles of the Declaration of Independence were indisputably legal principles. "Full power to levy war, conclude peace, contract alliances, establish commerce, and to do all other acts and things which Independent States may of right do" came straight from that universal jurisprudence which had been elaborated in the treatises of Grotius, Pufendorf, Burlamaqui, Vattel and others. These treatises were an essential and significant part of the minimal equipment of any lawyer of erudition in the eighteenth century. ${ }^{26}$ It will be remembered that a majority of the delegates to the convention soon to be convened were lawyers and that among the more influential were many of an enviable learning. ${ }^{27}$ Whenever in terms or by implication they spoke

25. See McLaugelin, A Constitumonal History of the United States, c. 12 (1935) ; Warren, The Making of the Constrtution, pt. I, c. 1 and passim (1928).

26. It is said that John Jay began his preparation for the bar by reading Grotius, De Jure Belli ac Pacis. Pelcew, John Jay 12 (1892). Robert Morris wrote from Philadelphia during the Constitutional Convention to his sons in Europe: "The law of Nations, a knowledge of the Germanic system and the Constitutions of the several governments in Europe, and an intimate acquaintance with ancient and modern history are essentially necessary to entitle you to participate in the honor of serving a free People in the administration of this Government." WARREN, op. cit. supra note 25, at 240. See also Brown, LIFE of Oliver EllsWORTH 242 (1905). Like instances may be multiplied almost ad libitum.

27. Warren notes that of the fifty-five who attended thirty-three had been lawyers and of these ten had been judges. Op. cit. supra note 25 , c. 2 . With few exceptions, the leaders were lawyer-statesmen of a notable distinction. The several plans were prepared and sponsored by such men: James Madison and Edmund Randolph of Virginia, William Paterson of New Jersey, and Charles Pinckney of South Carolina. The important Committee of Detail consisted, in addition to Nathaniel Gorham of Massachusetts, a businessman of prior experience in public affairs, of Oliver Ellsworth of Connecticut, Edmund Randolph of Virginia, John Rutledge of South Carolina, and James Wilson of Pennsylvania. The important Committee of Style consisted, in addition to Rufus King of Massachusetts, another businessman of significant public experience, of Alexander Hamilton of New York, William Samuel Johnson of Connecticut, James Madison of Virginia, and Gouverneur Morris of Pennsylvania. 
or wrote with reference to the Law of Nations, they were indulging no mere flights of hopeful rhetoric. They were as realistic as Lord Mansfield, as practical as the examples of Blackstone.

In such a climate the Constitutional Convention began its substantive work, after organization had been effected and plans presented, by resolving that "a national government ought to be established." 28 Presenting the Virginia Plan, which "became the basis of the work of the Convention and, expanded and developed, eventually grew into the Constitution as adopted," 29 Edmund Randolph introduced his enumeration of the defects of confederation as follows:

"1. that the confederation produced no security against foreign invasion; congress not being permitted to prevent a war nor to support it by their own authority-Of this he cited many examples; most of which tended to shew, that they could not cause infractions of treaties or of the law of nations, to be punished: that particular states might by their conduct provoke war without controul; and that neither militia nor draughts being fit for defence on such occasions, enlistments only could be successful, and these could not be executed without money." 30

Of Randolph's examples, "infractions of treaties or of the law of nations" were considered thereafter in the Convention chiefly in relation to proposals for a national judiciary. It is clear that the delegates regarded them as pre-eminently practical problems in the organization and administration of justice. The ninth of the Randolph Resolutions in which the Virginia Plan was presented called for the establishment of a national judiciary "to consist of one or more supreme tribunals, and of inferior tribunals to be chosen by the National Legislature," and proposed further "that the jurisdiction of the inferior tribunals shall be to hear \& determine in the first instance, and of the supreme tribunal to hear and determine in the dernier resort, all

28. 1 Records of the Federal Convention of 1787, 30 (Farrand ed. 1911) (hereinafter cited as FARRAND); and see Madison's Notes in 1 id. at 33-35. See also WARREN, op. cit. supra note 25, at 146-151, 233.

Jefferson, author of the Declaration of Independence, had written to Monroe in 1785, "The interests of the States ought to be made joint in every possible instance, in order to cultivate the idea of our being one Nation"; to Madison in 1786, "The politics of Europe rendered it indispensably necessary that with respect to everything external we be one nation firmly hooped together"; again to Madison in 1786, "To make us one nation as to foreign concerns, and keep us distinct in domestic ones, gives the outline of the proper division of power between the general and particular Governments"; and to Carrington in 1787, "My general plan would be to make the States one as to everything connected with foreign nations, and several as to everything purely domestic." WARREN, op. cit. supra note 25 , at 14, $46,47,382$.

29. 3 FarRand 593.

30. Madison's Notes in 1 Farrand 19. Invasions of the rights of an ambassador were among Randolph's examples. McHenry's Notes in 1 id. at 25. 
piracies \& felonies on the high seas, captures from an enemy; cases in which foreigners or citizens of other States applying to such jurisdictions may be interested, or which respect the collection of the National revenue; impeachments of any National officers, and questions which may involve the national peace and harmony." 31

The Pinckney Plan, introduced by Charles Pinckney of South Carolina at the same time as the Virginia Plan-and assuredly of more importance than some have assumed-is noteworthy here for at least two reasons: first, it appears to have put in issue for the first time the question whether there should be any provision for inferior national courts, other than courts of admiralty; and second, it conceded that there should be an appeal to a supreme national tribunal "from the judicial Courts of the several States in all Causes wherein Questions shall arise on the Construction of Treaties made by the U. S.- - or on the Law of Nations-or on the Regulations of U. S. concerning Trade and Revenue-or wherein U. S. shall be a Party." 32 Thus, notwithstanding a cleavage foreshadowed between defenders of states' rights and proponents of national power with respect to the structure of a national judiciary, there appears to have been an impressive measure of agreement at the outset that the Law of Nations and treaties must be the subjects, immediately or ultimately, of a paramount national concern.

The extent to which there was such an understanding among the delegates was again brought to the fore, a fortnight later, when William Paterson introduced the New Jersey Plan. The introduction of this plan marked a notable rallying of the supporters of states' rights. It was offered as a substitute for the Virginia Plan, widely regarded among delegates from the smaller states as too nationalistic. Notwithstanding, the New Jersey Plan proposed that "a federal Judiciary be established to consist of a supreme Tribunal" and "that the Judiciary so established shall have authority to hear and determine in

31. Madison's Notes in 1 FARRAND 21, 22. George Mason of the Virginia delegation had written Arthur Lee of Virginia, May 21, 1787, that "the most prevalent idea" envisaged, among other things, a national judiciary "with cognizance of all such matters as depend upon the law of nations, and such other objects as the local courts of justice may be inadequate to." WARREN, op. cit. supra note 25 , at 116 .

32. From an outline of the Pinckney Plan found among the Wilson Papers. 2 FARRAND 136. The same outline contains a proposal that the Congress should have "exclusive right of instituting in each State a Court of Admiralty... for all maritime causes which shall arise therein respectively." Ibid. When, a few days later, Rutledge of South Carolina attacked the Virginia proposal for the establishment of inferior federal tribunals, Wilson said: "the admiralty jurisdiction ought to be given wholly to the National Government, as it related to cases not within the jurisdiction of particular states, and to a scene in which controversies with foreigners would be most likely to happen." Madison's Notes in 1 FarRaNd 124. Concerning the importance of the Pinckney Plan, see WARREN, op. cit. supra note 25, at 115$116,142-144,239-240,391$ n., 803-804. 
the first instance on all impeachments of federal officers, \& by way of appeal in the dernier resort in all cases touching the rights of Ambassadors, in all cases of captures from an enemy, in all cases of piracies \& felonies on the high seas, in all cases in which foreigners may be interested, in the construction of any treaty or treaties, or which may arise on any of the Acts for regulation of trade, or the.collection of the federal Revenue." 33

It will be observed at once that the New Jersey Plan envisaged national judicial authority with respect to international matters much as the Virginia Plan had envisaged it, albeit as exclusively an appellate jurisdiction, while describing it in somewhat more of detail. Included were topics long since become stock examples of a necessary recourse to the Law of Nations in national courts-piracies, captures, and ambassadorial privileges-as well as cases involving the construction of treaties, the interests of foreigners, and to some extent matters of trade. Assuredly no more was needed in the late eighteenth century to alert the mind of any informed lawyer to the embracing corpus of universal law. Examining Paterson's plan, Madison's first question was: "Will it prevent those violations of the law of nations \& Treaties which if not prevented must involve us in the calamities of foreign wars?" 34 The Convention was in substantial agreement that there must be a national judiciary and that it must have, at least in the last resort, a paramount authority with respect to the Law of $\mathrm{Na}$ tions and treaties. ${ }^{35}$ It was not yet assured that there would be provision for inferior national courts. ${ }^{36}$ Details of the judicial power were still to be worked out. By July 18th, however, the Convention was able to resolve unanimously: "That the jurisdiction of the national Judiciary shall extend to cases arising under laws passed by the general Legislature, and to such other questions as involve the National peace and harmony." 37

33. Madison's Notes in 1 FarRand 244. On the genesis of the New Jersey Plan see $3 \mathrm{id}$. at 611 .

34. Madison's Notes in 1 FARRAND 316. Madison continued: "The tendency of the States to these violations has been manifested in sundry instances. The files of Congs. contain complaints already, from almost every nation with which treaties have been formed. Hitherto indulgence has been shown to us. This cannot be the permanent disposition of foreign nations. A rupture with other powers is among the greatest of national calamities."

35. James Wilson remarked in debates of June 25th: "We have unanimously agreed to establish a general government-That the powers of peace, war, treaties, coinage and regulating of commerce, ought to reside in that government." "Yates' Notes in 1 FARRAND 413.

36. The proposal had been saved for the time being, at least, by a divided vote, before the New Jersey Plan was introduced. Madison's Notes in 1 FarRand 124125. It was agreed to without dissent on Juily 18th. 2 id. at 45-46. See WARREN, op. cit. supra note 25 , at $325-327$.

37. 2 FarRand 39. 
However retarded the pace may have seemed at the time to those who had already labored for nearly two months in the summer heat of Philadelphia, there had been progress indeed. The difficult and at times disruptive problem of representation in the two branches of a national legislature had been substantially resolved. There was to be a national judiciary, consisting at least of a supreme tribunal, and having an ultimate and paramount jurisdiction in cases involving "the national peace and harmony." There remained, among others, the uniquely difficult problem of assuring an effective supremacy for national laws. It had been recognized from the beginning that assurance of such supremacy would be nothing less than the keystone of the arch of an effective national organization.

Obviously it would not be enough to say simply that national laws are supreme. As regards most of the international matters which were so much and so consistently in the minds of the delegates, the Articles of Confederation had purported to delegate an exclusive power to "the United States, in Congress assembled," and to impose corresponding prohibitions upon the states; but the state commitment to "abide by the determinations of the United States, in Congress assembled, on all questions which by this confederation are submitted to them," had proved a futile gesture. ${ }^{38}$ Accordingly, the Virginia Plan had proposed a power in the national legislature to negative all contravening state laws, together with a power "to call forth the force of the Union agst. any member of the Union failing to fulfill its duty." 39 Significantly enough, the idea of coercion by force had reappeared in the New Jersey Plan which, as initially presented, would have authorized the executive "to call forth ye power of the Confederated States . . . to enforce and compel an obedience" to national acts and treaties. ${ }^{40}$ The Virginia Plan' contemplated further a "council of revision," consisting of "the Executive and a convenient number of the National Judiciary," which would have a suspensive veto both of acts of the national legislature and of the exercise by the national legislature of its power to negative state acts. ${ }^{41}$

As the debates progressed, delegates from large states and small became increasingly conscious that coercion by force would be war and that cumbersome schemes for disallowance would be insufficient and calculated to involve the gravest difficulties in administration. ${ }^{42}$

38. Cf. Artictes of Confederatton, Arts. 6, 9, and 13; 1 Stat. 4, 5, 6, 8 (1781).

39. Madison's Notes in 1 Farrand 21.

40. $I d$. at 245 .

41. Id. at 21 .

42. On coercion by force, see WARREN, op. cit. supra note 25 , at $171-172$; and on the proposed negative of state laws, id. at 164-171, 316-324. 
There was an alternative idea in the proposal incorporated in the Paterson Resolutions "that all Acts of the U. States in Congs. made by virtue $\&$ in pursuance of the powers hereby \& by the articles of confederation vested in them, and all Treaties made \& ratified under the authority of the U. States shall be the supreme law of the respective States so far forth as those Acts or Treaties shall relate to the said States or their Citizens, and that the Judiciary of the several States shall be bound thereby in their decisions, any thing in the respective laws of the Individual States to the contrary notwithstanding." 43 Here was the idea of supremacy, a coercion of law and not of arms, perhaps the most significantly enduring idea to come out of the Convention.

At the conclusion of prolonged and at times acrimonious debate on representation in the two houses of the national legislature, and after disillusionment with respect to both coercion by force and a national negative had become general, the principle of supremacy was taken up and voted unanimously on July 17 th as follows:

"Resolved that the legislative acts of the United States made by virtue and in pursuance of the articles of Union and all Treaties made and ratified under the authority of the United States shall be the supreme law of the respective States as far as those acts or Treaties shall relate to the said States, or their Citizens and Inhabitants-and that the Judiciaries of the several States shall be bound thereby in their decisions, anything in the respective laws of the individual States to the contrary notwithstanding." 44

This resolution was referred without substantive change to the Committee of Detail, ${ }^{45}$ by which it was later reported in an improved text making national laws supreme over state constitutions as well as state laws and providing that "the Judges in the several States" rather than "the Judiciaries of the several States" shall be bound thereby in their decisions. ${ }^{48}$ On Rutledge's motion, agreed to unanimously on August 23d, "This Constitution and the Laws of the United States made in pursuance thereof" was substituted for "The Acts of the Legislature of the United States made in pursuance of this

43. Madison's Notes in 1 FarRand 245.

44. 2 FarRand 22 . Jefferson had developed the idea of judicial enforcement of restraints on contravening state laws, in preference to a national negative, in a letter to Madison of June 20,1787, but the letter could hardly have arrived from Paris before the Convention voted on July 17 th. WARREN, op. cit. supra note 25 , at 168.

45. 2 Farrand 132.

46. Id. at 183 . 
Constitution." 47 On Madison's motion, agreed to unanimously on August 25th, "all treaties made" was expanded to read "all treaties made or which shall be made." 48 The Committee of Style reported on September 12th without substantive change the text which was to be approved. ${ }^{49}$ Thus was coercion of law and not of arms initiated and accepted. If the obvious and oft expressed need for an undivided national responsibility and power in all that pertained to relations with other nations, so widely appreciated among the delegates, is borne in mind, it is no exaggeration to say that this was pre-eminently among their greater achievements. Perhaps it was their greatest achievement. It is noteworthy that the idea was initiated in terms first put forward in behalf of the smaller states, that it was the subject of much sober reflection, and that it carried the Convention with no dissenting vote.

At this point we may pass over the later debates, which were concerned more largely with the details of legislative and executive organization and power, in order to bring together the various provisions of the Constitution which would serve to implement the national power in matters of international concern. However familiar these various provisions may have since become, separately or in context, it is only as an aggregate that they may be appraised significantly in the perspective of the Convention. Only thus may we understand fully what is meant today when it is said: "Governmental power over internal affairs is distributed between the national government and the several states. Governmental power over external affairs is not distributed, but is vested exclusively in the national government." 50

The significance of the aggregate becomes immediately apparent when we look at the provisions of Article $I$ of the draft Constitution with respect to legislative power. "All legislative powers herein granted" were to be vested in a Congress of the United States $(I, 1)$ and, largely as elaborated in the Committee of Detail, ${ }^{51}$ were to include the power to raise revenue to "provide for the common defense and general welfare of the United States" ( $I, 8,1)$, "to regulate commerce with foreign nations, and among the several States, and with the Indian tribes" ( $I, 8,3)$, "to establish an uniform rule of naturali-

47. Id. at 381 ; Madison's Notes id. at 389.

48. 2 Farrand 409; Madison's Notes id. at 417. According to Madison's Notes, "This insertion was meant to obviate all doubt concerning the force of treaties preexisting, by making the words 'all treaties made' to refer to them, as the words inserted would refer to future treaties."

49. 2 FArRand 603.

50. Justice Sutherland in United States v. Belmont, 301 U.S. 324, 330 (1937).

51. See McLaughlin, op. cit. supra note 25, at 180; WARREN, op. cit. supros note 25 , at 384-391. 
zation" $(I, 8,4)$, "to coin money, regulate the value thereof, and of foreign coin" ( $I, 8,5)$, "to define and punish piracies and felonies committed on the high seas, and offenses against the law of nations" $(I, 8,10)$, "to declare war, grant letters of marque and reprisal, and make rules concerning captures on land and water" ( $I, 8,11)$, "to raise and support armies" ( $I, 8,12)$, "to provide and maintain a navy" ( $I, 8,13)$, "to make rules for the government and regulation of the land and naval forces" (I, 8, 14), "to provide for calling forth the militia to execute the laws of the Union, suppress insurrections, and repel invasions" ( $I, 8,15)$, and "to make all laws which shall be necessary and proper for carrying into execution the foregoing powers, and all other powers vested by this Constitution in the Government of the United States, or in any department or officer thereof" $(I, 8,18)$. Saving only the making of treaties and the sending and receiving of diplomatic representatives, which were reserved for the article to follow on the executive department, the enumeration of Article I covered the whole area of external affairs as comprehensively in its time as exceptional foresight and superior craftsmanship could cover it. The broad generalities of tentative plans and resolutions were here detailed without subtracting at all from the scope of a desired generality. War, peace, commerce and revenue, and "all other acts and things which Independent States may of right do," were embraced effectively; ${ }^{52}$ and in further assurance that national responsibility and power should be undivided in relations with other nations it was stipulated that "no State shall enter into any treaty, alliance, or confederation" or "grant letters of marque and reprisal" (I, 10, 1), that "no State shall, without the consent of Congress, lay any imposts or duties on imports or exports, except what may be absolutely necessary for execution of its inspection laws" (I, 10, 2), and that "no State shall, without the consent of Congress, lay any duty of tonnage, keep troops, or ships of war in time of peace, enter into any agreement or compact with another State, or with a foreign power, or engage in war, unless actually invaded, or in such imminent danger as will not admit of delay" ( $I, 10,3$ ).

Under Article II of the Constitution the national executive power was to be vested in a President of the United States of America (II, 1, 1) who was to be Commander-in-Chief of the armed forces (II, $2,1)$ and to have power "by and with the advice and consent of the Senate, to make treaties, provided two-thirds of the Senators present

52. Commenting on the qualifications of a federal legislator, Madison was to observe: "He ought not to be altogether ignorant of the law of nations; for that, as far as it is a proper object of municipal legislation, is submitted to the federal government." The FEDERALIST, No. 53 at 369 (1 Bourne ed. 1901). 
concur" (II, 2, 2). The President was also to nominate and, by and with the advice and consent of the Senate, to appoint "ambassadors, other public ministers and consuls" (II, 2, 2), to receive "ambassadors and other public ministers" and to "take care that the laws be faithfully executed" (II, 3). Thus, in concise and effective description, there was charted a course, which would make of the national executive the sole organ of communication with other nations, and of legislative and executive together the strong arm of an undistributed national responsibility and power as often as intercourse with other nations might become the subject of a relevant concern. ${ }^{53}$

Provisions for the national judicial power were in the same significant pattern. Whatever might occur over the years in controversies certain to arise, the original charter of authority was to be concise yet sufficiently embracing. The judicial power of the United States was to be vested "in one Supreme Court, and in such inferior courts as the Congress may from time to time ordain and establish" (III, 1). It was to extend, in the familiar formula,

"to all cases, in law and equity, arising under this Constitution, the laws of the United States, and treaties made, or which shall be made, under their authority; ${ }^{54}$ - to all cases affecting ambassadors, other public ministers and consuls;-to all cases of admiralty and maritime jurisdiction;- to controversies to which the United States shall be a party;-to controversies between two or more States;-between a State and citizens of another State;between citizens of different States;-between citizens of the same State claiming lands under grants of different States, and between a State, or the citizens thereof, and foreign States, citizens or subjects" (III, 2, 1).

The same section continued:

"In all cases affecting ambassadors, other public ministers and consuls, and those in which a State shall be a party, the Supreme Court shall have original jurisdiction. In all other cases before

53. Madison said: "The second class of powers, lodged in the general government, consists of those which regulate the intercourse with foreign nations, to wit: to make treaties; to send and receive ambassadors, other public ministers, and consuls; to define and punish piracies and felonies committed on the high seas, and offences against the law of nations; to regulate foreign commerce. . . ."

"This class of powers forms an obvious and essential branch of the federal administration. If we are to be one nation in any respect, it clearly ought to be in respect to other nations." THE Federalist, No. 42 at 285 (1 Bourne ed. 1901).

54. The words "treaties made, or which shall be made, under their authority" were inserted without dissent on August 27th, on Rutledge's motion, "comformably to a preceding amendment in another place." Madison's Notes in 2 FarRand 431. It would thus appear that the formula was taken with no substantive change from the text previously agreed to unanimously, on Madison's motion, for inclusion in the supremacy clause. See note 48 supra. 
mentioned the Supreme Court shall have appellate jurisdiction, both as to law and fact, with such exceptions and under such regulations as the Congress shall make" (III, 2, 2).

Commenting upon the importance of these sections, in matters affecting foreign nations, John Jay was soon to remark that "it is of high importance to the peace of America that she observe the law of nations towards all these powers." In the same number of The Federalist, Jay continued:

"Under the national government, treaties and articles of treaties, as well as the laws of nations, will always be expounded in one sense and executed in the same manner,-whereas, adjudications on the same points and questions, in thirteen states, or in three or four confederacies, will not always accord or be consistent; and that, as well from the variety of independent courts and judges appointed by different and independent governments, as from the different local laws and interests which may affect and influence them. The wisdom of the convention, in committing such questions to the jurisdiction and judgment of courts appointed by and responsible only to one national government, cannot be too much commended." ${ }_{55}$

Putting a "plain proposition" that "the peace of the whole ought not to be left at the disposal of a part," Alexander Hamilton was to be even more explicit. He said:

"The Union will undoubtedly be answerable to foreign powers for the conduct of its members. And the responsibility for an injury ought ever to be accompanied with the faculty of preventing it. As the denial or perversion of justice by the sentences of courts, as well as in any other manner, is with reason classed among the just causes of war, it will follow that the federal judiciary ought to have cognizance of all causes in which the citizens of other countries are concerned. This is not less essential to the preservation of the public faith, than to the security of the public tranquility. A distinction may perhaps be imagined between cases arising upon treaties and the laws of nations and those which may stand merely on the footing of the municipal law. The former kind may be supposed proper for the federal jurisdiction, the latter for that of the States. But it is at least problematical, whether an unjust sentence against a foreigner, where the subject of controversy was wholly relative to the lex loci, would not, if unredressed, be an aggression upon his sovereign, as well as one which violated the stipulations of a treaty or the general law of nations. And a still greater objection to the distinction would result from the immense difficulty, if not

55. The Fedealist, No. 3 at 22 (1 Bourne ed. 1901). 
impossibility, of a practical discrimination between the cases of one complexion and those of the other. So great a proportion of the controversies in which foreigners are parties, involve national questions, that it is by far most safe and most expedient to refer all those in which they are concerned to the national tribunals." 56

It is not particularly remarkable that Hamilton, strong nationalist that he was, should have presented these views in arguing for ratification, or that his penetrating mind and fluent pen should have contributed to expound so luminously a "plain proposition" concerning national judicial power. The remarkable thing is that there should have developed among all or most of the delegates at the Convention, with respect to every aspect of national power, so complete an understanding of the means required to implement the same "plain proposition" effectively. The results of their understandings and of their labors were incorporated in the great instrument signed on September 17th. The Law of Nations and treaties had been covered without parochial parsimony. The way to nationhood-cone nation firmly hooped together" with respect to everything external-had been

56. The Federalist, No. 80 at 112 (2 Bourne ed. 1901). Of maritime causes, Hamilton said: "The most bigoted idolizers of state authority, have not thus far shown a disposition to deny the national judiciary the cognizance of maritime causes. These so generally depend on the laws of nations, and so commonly affect the rights of foreigners, that they fall within the considerations which are relative to the public peace. The most important of them are, by the present Confederation, submitted to federal jurisdiction." Id. at 114. And see Hamilton's comments on the concurrent jurisdiction of federal and state courts, $i d$. No. 82, and on jury trial "where the question turns wholly on the laws of nations," id. No. 83.

See also the Lectures on Law of James Wilson, then Mr. Justice Wilson, delivered in the winter of $1790-91$ after the new government had been inaugurated. Justice Wilson was one of the most learned lawyers of his time. He had been a signer of the Declaration of Indepedence, a leader among the delegates to the Constitutional Convention, and as a delegate to his state convention had been influential in securing Pennsylvania's ratification. Justice Wilson said: "The relations existing between different states and the citizens of different states, and the rights and duties arising from those relations, form a constituent part of the common law. In that country, from which the common law has been brought, the law of nations has always been most respectfully and attentively adopted and regarded by the municipal tribunals, in all matters, concerning which it is proper to have recourse to that rule of decision. The law of nations, in its full extent, is a part of the law of England. The infractions of that law form a portion of her code of criminal jurisprudence. In civil transactions between the citizens of different states, that law has, in England, been received in its most ample latitude." 1 WILSON, WoRks, 374 (Bird Wilson ed 1804). "Should a similar conduct be observed by the tribunals of the United States, in the numerous and very important cases, to which the national constitution extends their judicial authority?" While Justice Wilson purported merely to pose the question, "the greatness of which is self-evident" his analysis of relevant constitutional provisions and his concluding encomiums left no doubt whatever as to his own view. "If a similar conduct ought to be observed by those tribunals; what an immense improvement has taken place in the application and administration of the law of nations!" "To every citizen of the United States, this law is not only a rule of conduct, but may be a rule of decision." "What a beautiful and magnificent prospect of government is now opened before you!" Id. at 359, 374-381. See Adams, The Legal Theories of James Wilson, 68 U. of PA. I. REv. 337 (1920). 
charted clearly. There was good prospect at last that the great principles of the Declaration of Independence might be realized. The Law of Nations was a constituent part of the English common law. Under the new dispensation, it would become a constituent part of the national law of the United States of America.

\section{IV}

The debates on ratification we shall by-pass, though the record contains much of interest in connection with our present inquiry, to come at once to the implementing of national judicial power. "It is well known that many of the chief objections to the Constitution were due to the broad scope of its provisions relative to the judicial power," that a considerable number of the amendments proposed by ratifying conventions were aimed at the judiciary article, and that "around that Article the opposition largely centered in the conventions in most of the States." ${ }^{57}$ Notwithstanding, the Constitution was ratified without changes in the judiciary article, and such concessions as the rallying forces of anti-nationalism were able to obtain were incorporated, not in the Constitution, but in the Judiciary Act of 1789.58 Some of these concessions have a bearing upon the subject here under investigation. If it is remembered that the first Judiciary Act was to continue without significant amendment until 1875, it will be apparent that they were to be more than transient accommodations. They were to illuminate or obscure a course with respect to the Law of Nations and treaties throughout most of the first one hundred years of the nation's constitutional progress.

The Act of 1789 established a system of subordinate federal courts, over the determined opposition of rallying anti-nationalist forces in the first Congress, but it made no attempt to implement fully the potential power of these courts in cases "arising under this Constitution, the laws of the United States, and treaties made, or which shall be made, under their authority." The wide range of power thus given was to remain largely dormant until after the Civil War. ${ }^{59}$ Offences against the Law of Nations, which had been the subject of so much concern to delegates in the Constitutional Convention, were covered by provisions vesting in the new federal district courts and circuit

57. Warren, Neze Light on the History of the Federal Judiciary Act of 1789, 37 Harv. L. REv. 49, 54, 55 (1923). (1789).

58. An Act to Establish the Judicial Courts of the United States, 1 Stat. 73

59. Warren, supra note 57, at 62, 67-70, passim; FRANkFurTer AND LANDIs, The Business of the Supreme Court 65 (1927). 
courts an exclusive jurisdiction of "all crimes and offences cognizable under the authority of the United States." ${ }^{00}$ Against the background provided by the record of debates in the Convention, and in the light of what we know now about the legislative history of the Judiciary Act, it is clear enough that these provisions were intended to embrace offences against the Law of Nations as part of a national common law with respect to crime. ${ }^{61}$ As is well known, however, the legislative purpose was to be largely frustrated in controversies which were to develop very early in the years to follow. ${ }^{62}$ As regards ambassadors, other public ministers and consuls, the Act vested the district courts with an exclusive but limited jurisdiction of "suits against consuls and vice-consuls," 63 and the Supreme Court exclusively with "all such jurisdiction of suits or proceedings against ambassadors, or other public ministers, or their domestics, or domestic servants, as a court of law can have or exercise consistently with the law of nations; and original, but not exclusive jurisdiction of all suits brought by ambassadors, or other public ministers, or in which a consul, or a viceconsul, shall be a party." ${ }^{84}$

As regards causes involving foreigners, which likewise had been the subject of a continuing concern to the delegates in Convention, the Act followed generally the pattern of the judiciary article in defining jurisdiction in terms of parties. In the same pattern, and in harmony with ideas then current concerning the several states and their citizens, causes concerning foreigners were generally grouped together with causes to which the citizens of different states were parties. There was one notable departure from pattern: the district courts were given cognizance "concurrent with the courts of the several States, or the circuit courts, as the case may be, of all causes where an alien sues for a tort only in violation of the law of nations or a treaty of the United States." ${ }^{65}$ Otherwise there was to be in the circuit courts an "original cognizance, concurrent with the courts of the several

60. 1 STAT. 73, $\$ 9,11$ (1789).

61. Under $\$ 9$ the jurisdiction of district courts was to embrace crimes "committed within their respective districts, or upon the high seas," and under $\$ 11$ the circuit courts were to have "concurrent jurisdiction with the district courts of the crimes and offences cognizable therein." Clauses in the draft bill which would have restricted the jurisdiction of crimes "cognizable under the authority of the United States" to crimes "defined by the laws of the same" or "defined by the laws of the land" were stricken out in the Senate. The deletions were "clearly intended to extend jurisdiction to crimes at common law and under the law of Nations." Warren, siepra note 57, at 51, 73, 77. And see The FEDERALIST, No. 42 (Madison).

62. The subsequent misadventures of national criminal jurisdiction will be discussed in the sequel to this paper.

63. 1 SтAт. $73, \$ 9$ (1789).

64. Id., $\$ 13$.

65. Id., \$9. Cf. The Federalist, No. 80 (Hamilton), quoted in text at note 56. 
States, of all suits of a civil nature at common law or in equity, where the matter in dispute exceeds, exclusive of costs, the sum or value of five hundred dollars, and the United States are plaintiffs, or petitioners; or an alien is a party, or the suit is between a citizen of the State where the suit is brought, and a citizen of another State." 68 Herein was the provision to become famous and difficult as the so-called diversity clause. The section following provided for removals from the state courts. ${ }^{67}$ Another section gave the Supreme Court an "exclusive jurisdiction of all controversies of a civil nature, where a state is a party, except between a state and its citizens; and except also between a state and citizens of other states, or aliens, in which latter case it shall have original but not exclusive jurisdiction." 88 Thus there were compromises, limitations and resulting ambiguities, but the broad outlines of an intended national jurisdiction with respect to foreigners were fairly clear.

Having noted that foreigners and citizens of the several states were grouped together in provisions for a national jurisdiction, we should note further that in areas clearly envisaged but none too sharply defined they were also made the subjects of a general national law. Here we come to another of the Act's notable compromises, the famous Section 34, which provided: "That the laws of the several states, except where the Constitution, treaties or statutes of the United States shall otherwise require or provide, shall be regarded as rules of decision in trials at common law in the courts of the United States in cases where they apply." The provision appears as the next to the last section of the statute only because it came in as a Senate amendment and was adopted late in the debates. Otherwise it should have followed immediately after the sections dealing with the jurisdiction of the circuit courts. ${ }^{69}$ Its import becomes clear enough, in broad outline, if we recall again that the Constitution accepted the Law of Nations as national law, that this law governed individuals no less than states, and that its corpus embraced, not only a multiplicity of matters to be attributed later to so-called public international law, but also the law of merchants and the law maritime. Obviously the famous Section 34 aimed to describe among other things the law applicable where socalled diversity jurisdiction might be exercised; obviously it was intended to reserve to local law more than was to be conceded years later

66. 1 Stat. 73, §11 (1789).

67. $I d$., $\$ 12$.

68. Id., $\S 13$.

69. Warren, op. cit. supra note 57 , at 108 . 
in some of the eccentric proliferations of the famous case of Swift v. Tyson; ${ }^{70}$ and obviously it was designed to make the laws of the several states rules of decision only "in cases where they apply," in terms excepting cases "where the Constitution, treaties or statutes of the United States shall otherwise require or provide." In the protracted debates which were to ensue in later years with respect to the import of this section, its limitations or exceptions appear to have been increasingly neglected. We dare say that no informed lawyer of the late eighteenth century, momentary political passions aside, would have read it as meaning that the Law of Nations was to be subordinated in any circumstances in the exercise of so-called diversity jurisdiction or otherwise to the laws of the several states.

Closely related to matters of concern to foreigners and to the customs of merchants were matters maritime. The principal part of the commerce upon which the prosperity of the thirteen states depended was foreign and maritime. As hitherto observed, the law of this commerce was found in the early maritime codes and in the customs and practices generally observed in maritime countries. As hitherto observed, also, the law maritime was already a jurisprudence of impressive age and maturity when the United States became a nation. The states as colonies had accumulated a considerable experience in its administration. When Justice Wilson asserted somewhat later that it was "not the law of a particular country, but the general law of nations," ${ }^{71}$ he was stating no novel doctrine. The proposition had been long since accepted generally in America. In the Constitutional Convention there had been occasional but notably consistent recognition that the law maritime must be a matter of national concern and that it should be administered by national judicial authority. The Constitution had given Congress authority "to regulate commerce with foreign nations, and among the several States," and had extended the national judicial power "to all cases of admiralty and maritime jurisdiction." 72 This latter power was implemented by the first Judiciary Act in the provision vesting the district courts with "exclusive original cognizance of all civil causes of admiralty and maritime jurisdiction . . . saving to suitors, in all cases, the right of a common law remedy, where the common law is competent to give it." 73 The saving clause was a concession to genuine and apparently

70. 16 Pet. 1 (U.S. 1842). The proliferations of Swift v. Tyson will be discussed in the sequel to this paper.

71. 1 WIIson, Works 375 (Bird Wilson ed. 1804).

72. See The Federalist, No. 80 (Hamilton), quoted in note 56 supra.

73. 1 Stat. 73, \$9 (1789). 
widespread concern about jury trial. ${ }^{74}$ As regards every substantive aspect of the maritime law, the implementing was intended to be uniform and complete.

Probably the most important provisions of the Judiciary Act of 1789 were those which vested the Supreme Court with authority to review the decisions of state courts. The Supreme Court was to have an appellate jurisdiction "from the circuit courts and courts of the several states, in the cases hereinafter specially provided for." 75 In the cases "specially provided for" in the famous Section 25 there was to be decisive assurance, once the section had passed the test of constitutionality, that the national law on matters of international concern need suffer no impairment from local jealousies or from a discord of local laws. Section 25 provided:

"That a final judgment or decree in any suit, in the highest court of law or equity of a State in which a decision in the suit could be had, where is drawn in question the validity of a treaty or statute of, or an authority exercised under the United States, and the decision is against their validity; or where is drawn in question the validity of a statute of, or an authority exercised under any State, on the ground of their being repugnant to the constitution, treaties or laws of the United States, and the decision is in favour of such their validity, or where is drawn in question the construction of any clause of the constitution, or of a treaty, or statute of, or commission held under the United States, and the decision is against the title, right, privilege or exemption specially set up or claimed by either party, under such clause of the said Constitution, treaty, statute or commission, may be re-examined and reversed or affirmed in the Supreme Court of the United States upon a writ of error."

The constitutionality of the "revising power" thus vested in the Supreme Court by Section 25 was first put sharply and dramatically to the test, as every lawyer knows, in the famous case of Martin $v$. Hunter's Lessee. ${ }^{76}$ Litigation had arisen out of conflict between the treaties with Great Britain and the Virginia laws of escheat. The Court of Appeals of Virginia had virtually defied the Supreme Court of the United States to take up the case under Section 25 and resolve the conflict. It is enough to recall that the case was taken up, the conflict resolved, and the constitutionality of Section 25 completely

74. Cf. Hamilton, The Feneralist, No. 83, at 144 (2 Bourne ed. 1901) : "I feel a deep and deliberate conviction that there are many cases in which the trial by jury is an ineligible one. I think it so particularly in cases which concern the public peace with foreign nations; that is, in most cases where the question turns wholly on the laws of nations. Of this nature, among others, are all prize cases."

75. 1 Stat. 73, \&13 (1789).

76. 1 Wheat. 304 (U.S. 1816). 
sustained. Justice Story's opinion in the case was notable, among other things, for its emphasis upon two important objectives of the judiciary article of the Constitution: first, the safeguarding of foreigners or non-citizens against such local prejudices or passions as might prevail in a state court; and second, the assuring of an essential "uniformity of decisions throughout the whole United States, upon all subjects within the purview of the Constitution." 77 That cases arising under the Law of Nations and treaties were considered "subjects within the purview of the Constitution" was made clear enough.

Persisting contentions on the score of constitutionality were rejected a few years later in the even more famous case of Cohens $v$. Virginia." Again emphasizing "the necessity of uniformity, as well as correctness in expounding the Constitution and laws of the United States," Chief Justice Marshall took this occasion to declare:

"That the United States form, for many, and for most important purposes, a single nation, has not yet been denied. In war, we are one people. In making peace, we are one people. In all commercial regulations, we are one and the same people. In many other respects, the American people are one; and the government which is alone capable of controlling and managing their interests in all these respects, is the government of the Union." 79

Following the Judiciary Act of 1789, there were no significant changes in the national judicial system until after the Civil War. Issues concerning national versus state authority were presented in a number of important controversies. The Supreme Court generally resolved these controversies, as opportunity presented, in favor of the national power; ${ }^{80}$ but otherwise the federal courts continued incapable, under the earlier statute, of exercising the full powers contemplated by the Constitution in matters of international concern. The major controversies having been put at rest by the outcome of the Civil War, the Congress in 1875 made a notable addition to the laws implementing national judicial authority. The addition was included in Section 1 of the Act of 1875 which provided:

77. "If there were no revising authority to control these jarring and discordant judgments, and harmonize them into uniformity," said Justice Story, "the laws, the treaties, and the Constitution of the United States would be different in different States, and might, perhaps, never have precisely the same construction, obligation, or efficacy, in any two States." Id. at $347,348$.

78. 6 Wheat. 264 (U.S. 1821).

79. Id. at 413, 416. See Warren, Legislative and Judicial Attacks on the Sitpreme Court of the United States-A History of the Twenty-Fifth Section of the Jiticiary Act, 47 AM. L. REv. 1, 161 (1913).

80. See 1 Warren, The Supreme Court in United States History, c. 8 ct seq. (1932). 
"That the circuit courts of the United States shall have original cognizance, concurrent with the courts of the several States, in all suits of a civil nature at common law or in equity, where the matter in dispute exceeds, exclusive of costs, the sum or value of five hundred dollars, and arising under the Constitution or laws of the United States, or treaties made, or which shall be made, under their authority, or in which the United States are plaintiffs or petitioners, or in which there shall be a controversy between citizens of different States or a controversy between citizens of the same State claiming lands under grants of different States, or a controversy between citizens of a State and foreign states, citizens, or subjects; and shall have exclusive cognizance of all crimes and offenses cognizable under the authority of the United States, except as otherwise provided by law, and concurrent jurisdiction with the district courts of the crimes and offenses cognizable therein." ${ }^{81}$

Thus the vast range of power which had lain dormant in the Constitution since 1789 was substantially implemented. Thus the federal courts became at last "the primary and powerful reliances for vindicating every right given by the Constitution, the laws, and treaties of the United States." 82 Thereafter any suit asserting such a right could be begun in a federal court and, if begun in a state court, could be removed to a federal court for disposition.

In 1891 the structure and the efficiency of the federal judiciary were greatly improved by legislation providing for circuit courts of appeals; ${ }^{83}$ and in 1911 the circuit courts, never altogether satisfactory and long since outmoded, were finally abolished. ${ }^{84}$ The Act of 1911 was entitled "An Act to codify, revise, and amend the laws relating to the judiciary." Herein, for the first time, most of the old that was to be conserved and much that was new were brought together and arranged more or less systematically in the form of a "Judicial Code." In general, the earlier legislation affecting matters of international concern was reenacted in identic terms or with no more than minor textual adjustments or improvements. Original jurisdiction formerly in the circuit courts was now vested in the district courts, including, in the familiar words of the Act of 1789: "all crimes and offenses cognizable under the authority of the United States,"

81. An Act to determine the jurisdiction of circuit courts of the United States, and to regulate the removal of causes from state courts, and for other purposes, 18 Stat. 470 (1875).

82. FRANKFURTER AND LANDis, op. cit. sippra note 59 , at 65 .

83. An Act to establish circuit courts of appeals and to define and regulate in certain cases the jurisdiction of the courts of the United States, and for other purposes, 26 Stat. 826 (1891).

84. 36 Stat. 1167 (1911). 
"all suits against consuls or vice-consuls," "all civil causes of admiralty and maritime jurisdiction, saving to suitors in all cases the right of a common-law remedy where the common law is competent to give it," ${ }^{85}$ and "all suits brought by an alien for a tort only, in violation of the laws of nations or of a treaty of the United States." 86 Original jurisdiction of the district courts was also to include, in terms deriving from the Act of 1789 as supplemented by the Act of 1875 , but with an increase in the jurisdictional amount, all suits of a civil nature at common law or in equity arising "under the Constitution or laws of the United States, or treaties made, or which shall be made, under their authority," or "between citizens of different States," or "between citizens of a State and foreign States, citizens or subjects." 37 Section 34 of the Act of 1789 concerning the law applicable in so-called diversity cases was unaffected by repealing provisions and so continued unchanged.

Provisions defining the jurisdiction of the Supreme Court in matters of international concern came in like fashion from the Act of 1789. Those concerned with suits brought against or by ambassadors or other public ministers or in which a consul or vice-consul is a party reappeared in Section 233 of the new code; and the once bitterly contested but long since accepted provision for Supreme Court review of state court decisions reappeared in Section 237.88 Nor was there anything new or novel in Section 256 affirming generally in the courts of the United States a jurisdiction "exclusive of the courts of the several States" with respect to crimes cognizable under United States authority, civil causes in admiralty other than those covered by the saving clause, prizes and prize proceedings, and proceedings against diplomatic or consular personnel. ${ }^{89}$

For present purposes, it will not be necessary to consider in detail the changes which have been made in national judiciary legislation since 1911. An Act of 1914 extended the scope of the Supreme Court's appellate control over state courts by providing for review by certiorari in cases in which the disputed federal right had been

85. In an early case the justices of the Supreme Court had been unanimously and "decidedly of opinion, that every District Court in the United States, possesses all the powers of a court of Admiralty, whether considered as an instance, or as a prize court." Glass v. The Sloop Betsey, 3 Dall. 6, 16 (U.S. 1794). To the paragraph concerning admiralty and maritime jurisdiction, the Judicial Code now added: "of all prizes brought into the United States; and of all proceedings for the condemnation of property taken as prize." 36 STAT. 1091, § 24, ๆ 3 (1911).

86. 36 SтAт. 1091, § 24 ाโ 2, 3, 17, 18 (1911).

87. 36 SтAт. 1091, \$24, II 1 (1911).

88. 36 STAT. 1156 (1911), 28 U.S.C. $\$ 344$ (1946).

89. 36 STAT. 1160 (1911), 28 U.S.C. $\$ 371$ (1946). 
upheld. $^{90}$ An Act of 1916 narrowed somewhat the scope of obligatory review upon writ of error while at the same time extending correspondingly the range of state cases which the Supreme Court might take up on certiorari. ${ }^{91}$ It is noteworthy that, notwithstanding a steadily increasing pressure to relieve the Supreme Court of the burdens of obligatory review, the writ of error was left available for two types of state court decisions: "( 1 ) where the validity of a treaty or statute of, or an authority exercised under, the United States was drawn in question and the decision was against its validity; and (2) where the validity of a statute of, or an authority exercised under, any state on the ground of its repugnance to the Constitution, treaties or laws of the United States was drawn in question and the decision was in favor of its validity." 92 An Act of 1925 further revised these same provisions by omitting two clauses which had appeared initially in the Act of 1789-the clauses covering "an authority exercised under" the United States or any State-but otherwise left undisturbed such parts of the Judicial Code of 1911 as have been found of interest in connection with our present investigation. ${ }^{93}$

The whole body of national legislation concerning judicial organization, jurisdiction and procedure was again revised and codified, and this time even more comprehensively and systemmatically, in an Act of 1948 enacting into law Title 28 of the United States Code entitled "Judicial Code and Judiciary," ${ }^{94}$ and in another Act of 1948 enacting into law Title 18 of the United States Code entitled "Crimes and Criminal Procedure." 95 In these enactments are modernizations of phraseology, eliminations of the obsolete, and revisions to bring text into conformity with new rules of procedure; but as regards provisions pertinent to our present inquiry it appears from the text and the Reviser's Notes that no substantive changes have been intended. ${ }^{90}$ In the familiar sequence of Article III, section 2 of the Constitution with respect to the judicial power, cases arising under the Constitution, laws and treaties of the United States are now covered by modernized or streamlined versions of two familiar provisions: the one, derived from the Act of 1875 , defines the original jurisdiction of

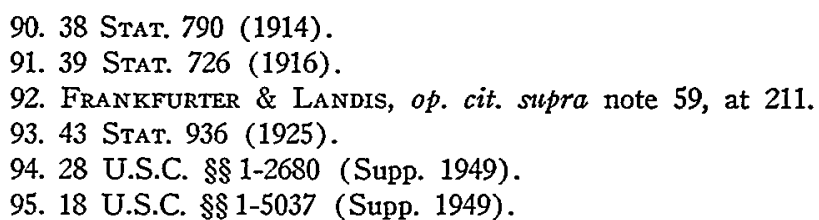

96. The familiar provision with respect to the criminal jurisdiction of the federal courts, which had appeared hitherto in the Act of 1789, the Act of 1875 and the Act of 1911, is now placed in revised text in the new Criminal Code as 18 U.S.C. $\$ 3231$ (Supp. 1949). 
district courts in civil actions; ${ }^{97}$ and the other, derived from the Act of 1789 , determines the scope of Supreme Court review of state court decisions. ${ }^{98}$ Cases affecting diplomats and consuls are covered substantially as they have been continuously since the Act of $1789 .^{99}$ So too are civil cases in admiralty, though the saving clause has now been given a "new look" thought to be "simpler and more expressive of the original intent of Congress." 100 Cases affecting foreigners continue subject to two formulations of national authority: the original jurisdiction of the district courts of "any civil action by an alien for a tort only, committed in violation of the law of nations or a treaty of the United States," derives without interruption from the Act of $1789 ;{ }^{101}$ and the diversity jurisdiction of the district courts in cases between the citizens of a state and "foreign states or citizens or subjects" derives similarly from the Act of 1789 as expanded by the Act of 1875.102 The delimitation of national and state laws as rules of decision in civil actions in courts of the United States is preserved substantially as it appeared originally in the Act of 1789 , Section $34 .{ }^{103}$ In brief, and in general, the implementing of national judicial power in matters of international concern is today in the pattern first detailed in 1789, first supplemented significantly in 1875, and since revised, chiefly in matters of detail, in the sequence of subsequent enactments noted.

\section{V}

Up to this point it has been clear that the Constitution was framed in firm reliance upon the premise, frequently articulated, that the United States must be one nation in all its relations with other nations; that in such relations it must have powers equal to its responsibilities as a free and independent nation; that in the aggregate of powers with which the Constitution invested the principal departments of the national government, together with expressed limitations upon the states, there was ample provision for an essential and undistributed national authority; and that the Law of Nations in all its

97. 28 U.S.C. $\$ 1331$ (Supp. 1950).

98. 28 U.S.C. $\$ 1257$ (Supp. 1950). On review of cases in the Courts of Appeals, see id., $\$ 1254$.

99. 28 U.S.C. $\$ \S 1351,1251$ (Supp. 1950).

100. 28 U.S.C. $\$ 1333$ (Supp. 1950). Prizes and prize proceedings are included as in the Act of 1911 . See note 85 sipra. The saving clause now reads: "saving to the libellant or petitioner in every case any other remedy to which he is otherwise entitled." Whether this is "more expressive of the original intent," as said in the Reviser's Notes, query? It is helpful to be assured that no substantive change was intended.

101. 28 U.S.C. $\$ 1350$ (Supp. 1950).

102. 28 U.S.C. $\$ 1332$ (Supp. 1950).

103. 28 U.S.C. \$1652 (Supp. 1950). 
aspects familiar to men of learning in the eighteenth century was accepted by the framers, expressly or implicitly, as a constituent part of the national law of the United States. The progress of this part of the national law would depend in large measure, it is obvious, upon the implementing of the national judicial power. The implementing was less than complete for many years; and there were ambiguities in its compromises which were bound to cause confusion. In one formulation or another, however, it should be apparent that the national judiciary legislation contained most of what was needed from the beginning. The heritage from English law was understood by the men who framed the Constitution. Many of the same men contributed significantly to the framing of the first Judiciary Act. The avenues of progress which that legislation opened to the Law of $\mathrm{Na}-$ tions in America have been maintained and improved throughout the ensuing years.

Against the background of legal heritage, constitution making, and statutory development which we have here reviewed, there remains to be considered the progress of the law in its judicial administration. There were to be some odd and some notable developments of the Law of Nations in the case law of the United States. These developments we shall make the subject of a sequel to the present paper. In the sequel we shall consider, as space may permit, the law of offences, the law of merchants, the law maritime, and what we have called for convenience the law of states. The latter, we may remind again, included most of that somewhat unassorted body of law and practice which would be described eventually as public international law. There were difficulties ahead in a nation organized on federal principles. The difficulties, their frustrations, and the extent to which they were successfully surmounted should provide subject matter enough for a sequel of some interest and practical importance. 